\title{
Penerapan Model Pembelajaran Kooperatif Tipe Group Investigation Dapat Meningkatkan Hasil Belajar Siswa dalam Menghitung Luas Segi Banyak di Kelas VI SDN. No. 028/XI Tanjung Tahun 2016/2017
}

\author{
Nadirman $^{1}$ \\ Guru di SDN. No. 028/XI Tanjung ${ }^{1}$ \\ Kecamatan Hamparan Rawang, Kota Sungai Penuh, Provinsi Jambi
}

\begin{abstract}
This study aims to improve the student's learning outcomes in calculating the wide of many facets by applying cooperative learning model of group investigation type. The study involved 18 students of sixth class year 2016/2017 at SDN. No. 028/XI Tanjung, Hamparan Rawang Subdistrict, Sungai Penuh City, Jambi Province. This research is a Classroom Action Research that conducted in two cycles (Cycle I and Cycle II). Each cycle is done through two meetings with four activities namely planning, implementation, observation, and reflection. The research data was collected through observation and test. The data were processed by using descriptive analysis and simple statistical test. Application of cooperative learning model of group investigation type brought about changes in student learning activities. All students follow the learning with enthusiasm, follow all the learning stages in accordance with the rules, and can work together in groups. Most students have also been able to communicate the results of group work in front of the class and also have dared to submit feedback on the presentation of the results of other group discussions. The implementation of cooperative learning model of group investigation type also improves the learning outcomes of sixth grade students in SDN. No. 028/XI Tanjung year 2016/2017. Student's learning outcomes seen from the mean and percentage of students who were able to fulfil the minimum criteria. Thus, cooperative learning model type group investigation can be an alternative to improve student learning outcomes in mathematics subjects, especially in calculating the wide of many facets.
\end{abstract}

Keywords: elementary school, group investigation, learning outcomes, mathematics

\section{PENDAHULUAN}

Matematika adalah salah satu mata pelajaran dasar yang perlu diajarkan sejak dini. Matematika menjadi salah satu mata pelajaran wajib di Sekolah Dasar (SD). Keberhasilan pembelajaran matematika di SD menjadi bekal siswa untuk belajar di jenjang pendidikan selanjutnya. Apabila guru gagal menanamkan keterampilan dasar matematika di SD maka siswa akan kesulitan dalam mempelajari matematika di jenjang pendidikan selanjutnya.

Salah satu masalah yang ditemui oleh guru kelas VI di SDN. No. 028/XI Tanjung adalah siswa mengalami kesulitan dalam mempelajari konsep dalam pembelajaran matematika yang berdampak pada rendahnya hasil belajar siswa. Belajar juga didefinisikan sebagai sebuah proses yang dilakukan individu untuk memperoleh pengetahuan dan pengalaman baru yang diwujudkan dalam bentuk perubahan tingkah laku yang relatif permanen dan menetap disebabkan adanya interaksi individu dengan lingkungan belajarnya (Irham dan Wiyani, 2013). Proses belajar erat kaitannya dengan hasil belajar. Hamalik (2004) mendefinisikan hasil belajar sebagai tingkat penguasaan yang dicapai oleh pelajar dalam mengikuti proses belajar mengajar sesuai dengan tujuan pendidikan yang ditetapkan. Selanjutnya, Susanto (2013) mengartikan hasil belajar sebagai perubahan yang terjadi pada diri siswa, baik yang menyangkut aspek kognitif, afektif, dan 
psikomotor. Hasil belajar menjadi bukti keberhasilan yang telah dicapai oleh seseorang (Winkel, 2009).

Hasil identifikasi masalah menunjukkan bahwa kegiatan pembelajaran masih berpusat pada guru, model pembelajaran yang digunakan masih konvensional, seperti ceramah, tanya jawab, dan pemberian tugas. Selain itu, hasil belajar siswa dalam pembelajaran masih termasuk dalam kategori rendah. Hasil tes penjajakan menunjukkan bahwa siswa memperoleh nilai terendah adalah 0 dan nilai tertinggi adalah 70 dengan nilai rata-rata sebesar 37,78. Sebagian besar siswa mendapatkan nilai kurang dari 60,00 yang menjadi kriteria ketuntasan minimum untuk kompetensi dasar. Penghitungan ketuntasan belajar menunjukkan bahwa hanya ada $44,44 \%$ siswa yang dinyatakan tuntas. Dengan demikian, guru perlu memperbaiki kualitas pembelajaran untuk mengatasi masalah tersebut.

Salah satu upaya yang dapat dilakukan untuk memperbaiki kualitas pembelajaran adalah dengan melakukan perubahan pada model pembelajaran yang digunakan. Guru boleh memilih model pembelajaran yang sesuai dan efisien untuk mencapai tujuan pendidikannya (Rusman, 2011). Pemilihan model pembelajaran harus dilakukan sesuai dengan kebutuhan siswa, karena masing-masing model pembelajaran memiliki tujuan, prinsip, dan tekanan yang berbeda-beda. Model pembelajaran adalah kerangka konseptual yang melukiskan prosedur yang sistematik dalam mengorganisasikan pengalaman belajar untuk mencapai tujuan belajar tertentu, dan berfungsi sebagai pedoman bagi para perancang pembelajaran dan para pengajar dalam merencanakan aktivitas belajar mengajar (Trianto, 2007). Model pembelajaran juga dapat diartikan sebagai kerangka konseptual yang melukiskan prosedur sistematis dalam mengorganisasikan pengalaman belajar untuk mencapai tujuan belajar (Suprijono, 2012). Model pembelajaran mengacu pada pendekatan yang akan digunakan, termasuk di dalamnya tujuan- tujuan pembelajaran, tahap-tahap dalam kegiatan pembelajaran, lingkungan pembelajaran, dan pengelolaan kelas. Dalam penerapannya, model pembelajaran harus dilakukan sesuai dengan kebutuhan siswa, karena masing-masing model pembelajaran memiliki tujuan, prinsip, dan tekanan yang berbeda-beda.

Model pembelajaran kooperatif adalah suatu model pembelajaran yang mana siswa bekerja dalam kelompokkelompok kecil secara kolaboratif yang anggotanya terdiri atas 4 sampai 5 orang dengan struktur kelompoknya yang bersifat heterogen. Keberhasilan belajar dari kelompok bergantung pada kemampuan dan aktivitas anggota kelompok, baik secara individual maupun secara kelompok (Solihatin dan Raharjo, 2007).

Berdasarkan analisis masalah, tindakan yang dipilih guru adalah memperbaiki model pembelajaran yang digunakan. Model pembelajaran yang dipilih adalah model pembelajaran kooperatif tipe group investigation. Model pembelajaran group investigation merupakan model pembelajaran yang paling kompleks. Model ini pertama kali dikembangkan oleh Thelan, kemudian dalam perkembangannya model ini di perluas dan dipertajam oleh Sharan dari universitas Tel Aviv (Trianto, 2009). Guru yang menerapkan model pembelajaran kooperatif tipe group investigation membagi kelas menjadi kelompokkelompok dengan anggota 5-6 siswa yang heterogen. Selanjutnya, siswa melakukan penyelidikan yang mendalam atas topik dan menyiapkan dan mempresentasikan laporannya kepada seluruh kelas.

Menurut Slavin, dalam Suwangsih dan Tiurlina (2006), langkah-langkah dalam menerapkan pembelajaran kooperatif tipe group ivestigastion adalah sebagai berikut mengidentifikasi topik dan pengorganisasian siswa ke dalam kelompok-kelompok, merencanaankan 
tugas belajar, melaksanakan penelitian/ investigasi, menyiapkan sebuah laporan akhir, menyajikan laporan akhir atau presentasi, dan evaluasi. Setiap model pembelajaran memiliki kelebihan dan kelemahan. Setiawan (2006) mendeskripsikan beberapa kelebihan dari model pembelajaran kooperatif tipe group investigation, yaitu memberi semangat untuk berinisiatif, kreatif, dan aktif, mengajarkan siswa untuk memecahkan/menangani suatu masalah, meningkatkan kerja sama, memberi kesempatan pada siswa untuk belajar berkomunikasi yang baik secara sistematis, meningkatkan partisipasi dalam membuat suatu keputusan, dan selalu berpikir tentang cara atau strategi yang digunaka sehingga didapat suatu kesimpulan yang berlaku umum.

Model pembelajaran kooperatif tipe group investigation dipilih karena dapat memberikan kesempatan bagi siswa untuk berpartisipasi dalam memecahkan masalah yang dikaji antar individu dalam kelompoknya untuk memperoleh kesepakatan dalam penyelesaian permasalahan yang diberikan oleh guru. Widiantara, Sedanayasa, dan Dibia (2014), pembelajaran matematika yang menerapkan model pembelajaran kooperatif tipe group investigation memperoleh hasil belajar yang lebih baik dibandingkan dengan pembelajaran yang konvensional. Dengan demikian, masingmasing siswa akan terlibat langsung dalam proses tersebut. Melalui model pembelajaran group investigation diharapkan aktivitas dan hasil belajar dapat ditingkatkan. Pemilihan model pembelajaran kooperatif tipe group investigation sesungguhnya menyangkut dua aspek yang relevan yaitu karakteristik siswa dan tingkat kesulitan materi ajar yang akan disampaikan.

Berdasarkan uraian tersebut, peneliti melakukan penelitian tindakan kelas yang berjudul "Penerapan Model Pembelajaran Kooperatif Tipe Group Investigation untuk
Meningkatkan Hasil Belajar Siswa dalam Menghitung Luas Segi Banyak di Kelas VI SDN. No. 028/XI Tanjung Tahun 2016/2017'. Penelitian ini bertujuan untuk meningkatkan hasil belajar siswa kelas VI dalam menghitung luas segi banyak di SDN. No. 028/XI Tanjung tahun 2016/2017 dengan menerapkan model pembelajaran kooperatif tipe Group Investigation.

\section{METODE PENELITIAN}

Jenis penelitian ini adalah Penelitian Tindakan Kelas (PTK). Arikunto (2013) menyatakan penelitian tindakan kelas adalah suatu pencermatan terhadap kegiatan belajar berupa sebuah tindakan yang sengaja dimunculkan dan terjadi dalam sebuah kelas secara bersamaan. Penelitian tindakan kelas juga dapat diartikan sebagai suatu pencermatan terhadap kegiatan yang sengaja dimunculkan dan terjadi dalam sebuah kelas (Aqib, 2009). Selanjutnya, menurut Kunandar (2013), penelitian tindakan kelas sebagai suatu penelitian tindakan (action research) yang dilakukan oleh guru yang sekaligus sebagai peneliti di kelasnya atau bersama-sama dengan orang lain (kolaborasi) dengan jalan merancang, melaksanakan, dan merefleksikan tindakan secara kolaboratif dan partisipatif yang bertujuan untuk memperbaiki atau meningkatkan mutu (kualitas) proses pembelajaran di kelasnya melalui suatu tindakan (treatment) tertentu dalam suatu siklus. Penelitian tindakan kelas ini dilaksanakan dalam dua siklus yaitu siklus I dan siklus II. Siklus I dilakukan sebanyak dua kali pertemuan, sedangkan siklus II dilakukan sebanyak dua kali pertemuan. Masing-masing siklus terdiri atas empat kegiatan, yaitu perencanaan, pelaksanakan, pengamatan, dan refleksi.

Kegiatan penelitian dilakukan di SDN. No. 028/XI Tanjung, Kecamatan Hamparan Rawang, Kota Sungai Penuh, Provinsi Jambi. Waktu Penelitian. Kegiatan penelitian dilakukan sejak bulan 
bulan Juli sampai dengan bulan November tahun 2016. Subjek Penelitian. Subjek dalam penelitian ini adalah siswa kelas VI SDN. No. 028/XI Tanjung yang berjumlah 18 orang.

Data yang dikumpulkan dalam penelitian tindakan kelas ini adalah data hasil belajar siswa. Data hasil belajar dikumpulkan dengan dua cara yaitu tes dan observasi. Data yang telah dikumpulkan diolah dan dianalisis untuk mengetahui tingkat keberhasilan suatu tindakan. Analisis yang digunakan adalah analisis deskriptif dan uji statistik sederhana. Uji statistik yang digunakan adalah penghitungan nilai rata-rata dan ketuntasan belajar.

Indikator keberhasilan dari penelitian tindakan kelas ini adalah meningkatnya hasil belajar siswa kelas VI SDN. No. 028/XI Tanjung tahun 2016/2017 pada mata pelajaran Matematika. Peningkatan hasil belajar mengacu pada Kriteria Ketuntasan Minimum (KKM) mata pelajaran dan KKM kompetensi dasar yang telah ditentukan oleh sekolah di awal tahun pelajaran 2016/2017 yaitu sebesar 60,00.

\section{HASIL DAN PEMBAHASAN Pratindakan}

Sebelum memberikan tindakan, guru mengadakan tes penjajakan terlebih dahulu pada siswa. Hasil tes penjajakan menunjukkan bahwa nilai yang diperoleh siswa berada pada rentang 0-70,00 (nilai terendah adalah 0 dan nilai tertinggi adalah $70,0)$. Nilai rata-rata yang diperoleh adalah 37,78. Apabila nilai yang diperoleh siswa dibandingkan dengan KKM kompetensi dasar maka diperoleh hasil bahwa sebanyak $44,44 \%$ siswa yang memenuhi KKM kompetensi dasar. Hasil ini yang menjadi dasar guru untuk melaksanakan penelitian tindakan kelas. Pemberian tindakan berupa penerapan model pembelajaran kooperatif tipe group investigation diharapkan dapat membantu meningkatkan hasil belajar siswa. Hasil siswa berdasarkan tes penjajakan yang telah dilakukan disajikan pada Tabel 1.

Tabel 1 Hasil tes penjajakan

\begin{tabular}{clccl}
\hline No & & NKM & Nilai & \multicolumn{1}{c}{ Keterangan } \\
\hline 1 & Ainun Septia & 60 & 40 & Tidak Tuntas \\
2 & Aldo Noviardi & 60 & 0 & Tidak Tuntas \\
3 & Arif Manardi & 60 & 60 & Tuntas \\
4 & Aufa Alfia & 60 & 60 & Tuntas \\
5 & Defindra Pratama & 60 & 60 & Tuntas \\
6 & Delta Elfiani & 60 & 30 & Tidak Tuntas \\
7 & Deski Ahmad Farel & 60 & 20 & Tidak Tuntas \\
8 & Enjel Lika & 60 & 10 & Tidak Tuntas \\
9 & Hegil Alfaro & 60 & 60 & Tuntas \\
10 & Lendra Ahmad & 60 & 40 & Tidak Tuntas \\
11 & Marisa Dina & 60 & 30 & Tidak Tuntas \\
12 & Rizky Amanda & 60 & 60 & Tuntas \\
13 & Roni Irawan & 60 & 60 & Tuntas \\
14 & Susan Aulia & 60 & 10 & Tidak Tuntas \\
15 & Tesya Wulandari & 60 & 60 & Tuntas \\
16 & Vina Intan & 60 & 0 & Tidak Tuntas \\
17 & Trisia Helen Sari & 60 & 70 & Tuntas \\
18 & Zandi Akbar & 60 & 10 & Tidak Tuntas \\
& Nilai Tertinggi & & 70,00 & \\
& Nilai Terendah & & 0 & \\
& Nilai Rata-Rata & & 37,78 & \\
& Ketuntasan Belajar & & 44,44 & \\
\hline
\end{tabular}




\section{Siklus I}

Kegiatan penelitian pada siklus I dilaksanakan pada hari Selasa, 23 Agustus 2016 (Pertemuan ke-1 Siklus I), hari Kamis, 25 Agustus 2016 (Pertemuan ke-2 Siklus I), dan hari Selasa, 30 Agustus 2016 (Evaluasi Hasil Belajar Siklus I). Kegiatan penelitian pada siklus I terdiri atas perencanaan, pelaksanaan, pengamatan, dan refleksi.

Pertama, perencanaan. Kegiatan perencanaan terdiri atas: menganalisis standar kompetensi dan kompetensi dasar, menyusun rencana pelaksanaan pembelajaran (RPP), menetapkan materi bahan ajar, menyiapkan media pembelajaran, dan menyusun alat evaluasi pembelajaran

Kedua, pelaknaan. Kegiatan pelaksanaan terdiri atas tiga kegiaatn, yaitu kegiatan awal, kegiatan inti, dan kegiatan penutup. Kegiatan awal terdiri atas guru masuk kelas dan memberikan salam, siswa berdoa dipimpin oleh ketua kelas, guru mengondisikan kelas dan memeriksa kehadiran siswa, guru memberikan nomor pengamatan kepada siswa, guru menyampaikan apersepsi sebelum pembelajaran dimulai, dan guru menyampaikan tujuan pembelajaran yang akan dipelajari. Kegiatan inti dilakukan dengan eksplorasi, elaborasi, dan konfirmasi. Eksplorasi dilakukan dengan cara: guru menjelaskan kepada siswa tentang pembelajaran yang akan dilakukan yaitu dengan model cooperative learning tipe groupinvestigation, guru menyajikan subtopik permasalahan yang akan diinvestigasi dan melibatkan siswa dalam mengidentifikasi topik tersebut, guru meminta beberapa siswa menjawab pertanyaan untuk menggali pengetahuan awal siswa tentang materi yang akan diajarkan, guru membagi siswa menjadi beberapa kelompok. satu kelompok terdiri atas 5-6 orang orang siswa yang dibentuk secara heterogen, dan kelompok siswa merencanakan topik permasalahan yang akan dipelajari. Elaborasi dilakukan dengan cara siswa melakukan investigasi sesuai topik pada masing-masing kelompok dan setiap kelompok menyiapkan laporan akhir yaitu berupa rencana kegiatan presentasi yang akan disajikan di depan kelas.

Selanjutnya, konfirmasi dilakukan dengan cara masing-masing perwakilan kelompok mempresentasikan hasil diskusinya, guru bersama siswa mengevaluasi hasil presentasi yang telah disajikan oleh masing-masing kelompok, dan siswa dan guru melakukan refleksi terhadap kegiatan pembelajaran yang telah dilaksanakan. Kegiatan penutup terdiri atas: guru bersama siswa membuat kesimpulan. Guru memberikan tes akhir, guru memberikan tindak lanjut terhadap proses pembelajaran, dan guru menutup pembelajaran dengan salam dan ber doa.

Ketiga, pengamatan. Hasil belajar dalam penelitian ini dinilai berdasarkan tes dan didukung oleh evaluasi non-tes berupa pengamatan mengenai aktivitas siswa dalam kegiatan pembelajaran. Secara ringkas, hasil observasi disajikan pada Tabel 2.

Tabel 2 Hasil pengamatan aktivitas siswa pada akhir Siklus I

\begin{tabular}{clcr}
\hline No & \multicolumn{1}{c}{ Indikator } & Jumlah & Persen \\
\hline 1 & Siswa mengikuti pembelajaran dengan antusias & 12 & 66,67 \\
2 & $\begin{array}{l}\text { Siswa mengikuti semua tahapan pembelajaran sesuai dengan } \\
\text { aturan }\end{array}$ & 14 & 77,78 \\
3 & Siswa dapat bekerja sama dalam kelompok & 12 & 66,67 \\
4 & $\begin{array}{l}\text { Siswa mampu menyampaikan hasil kerja kelompok di depan } \\
\text { kelas }\end{array}$ & 11 & 61,11 \\
5 & $\begin{array}{l}\text { Siswa berani menyampaikan tanggapan mengenai presentasi } \\
\text { hasil diskusi kelompok lain }\end{array}$ & 12 & 66,67 \\
\hline
\end{tabular}


Hasil pengamatan menunjukkan bahwa selama pembelajaran, sebagian besar siswa terlihat antusias mengikuti kegiatan pembelajaran. Sebagian besar siswa juga dapat mengikuti semua tahapan pembelajaran sesuai dengan aturan. Akan tetapi, masih terdapat beberapa siswa yang tidak mengetahui mengenai perubahan model pembelajaran yang digunakan. Akibatnya, siswa tersebut menjadi kurang antusias dalam kegiatan pembelajaran. Hasil pengamatan juga menunjukkan bahwa sebagian besar siswa dapat bekerja sama dalam kelompok. Siswa saling membantu dalam mengerjakan tugas yang diberikan oleh guru. Siswa yang memahami cara menyelesaikan soal mulai terlihat menjelaskan cara mengerjakan soal tersebut pada anggota kelompok yang belum paham. Model pembelajaran kooperatif tipe group investigation juga meningkatkan keberanian siswa dalam menyajikan hasil diskusi kelompok. Siswa juga semakin berani dalam menanggapi hasil diskusi kelompok lain.
Evaluasi hasil belajar Siklus I juga dilakukan dengan tes. Hasil evaluasi tersebut disajikan pada Tabel 3. Hasil penelitian menunjukkan bahwa siswa memperoleh nilai terendah sebesar 30,0 dan nilai tertinggi sebesar 80,0 dengan nilai rata-rata sebesar 56,11. Apabila nilai yang diperoleh siswa dibandingkan dengan KKM kompetensi dasar, diketahui bahwa terdapat $61,11 \%$ siswa yang memperoleh nilai yang memenuhi KKM kompetensi dasar. Hasil yang diperoleh ini meningkat dibandingkan dengan hasil tes siswa pada saat pratindakan yang mana siswa memperoleh nilai rata-rata sebesar 37,78 dan hanya terdapat $44,44 \%$ siswa yang memiliki nilai lebih besar atau sama dengan KKM kompetensi dasar. Hasil ini menunjukkan bahwa keberhasilan penerapan model pembelajaran kooperatif tipe group investigation sudah mulai terlihat. Dengan demikian, penerapan model pembelajaran kooperatif tipe group investigation akan dilanjutkan ke Siklus II.

Tabel 4 Hasil penelitian pada Siklus I

\begin{tabular}{clccl}
\hline No & & KKM & Nilai & \multicolumn{1}{c}{ Keterangan } \\
\hline 1 & Ainun Septia & 60 & 60 & Tuntas \\
2 & Aldo Noviardi & 60 & 30 & Tidak Tuntas \\
3 & Arif Manardi & 60 & 60 & Tuntas \\
4 & Aufa Alfia & 60 & 70 & Tuntas \\
5 & Defindra Pratama & 60 & 70 & Tuntas \\
6 & Delta Elfiani & 60 & 60 & Tuntas \\
7 & Deski Ahmad Farel & 60 & 30 & Tidak Tuntas \\
8 & Enjel Lika & 60 & 50 & Tidak Tuntas \\
9 & Hegil Alfaro & 60 & 80 & Tuntas \\
10 & Lendra Ahmad & 60 & 60 & Tuntas \\
11 & Marisa Dina & 60 & 50 & Tidak Tuntas \\
12 & Rizky Amanda & 60 & 70 & Tuntas \\
13 & Roni Irawan & 60 & 70 & Tuntas \\
14 & Susan Aulia & 60 & 30 & Tidak Tuntas \\
15 & Tesya Wulandari & 60 & 70 & Tuntas \\
16 & Vina Intan & 60 & 30 & Tidak Tuntas \\
17 & Trisia Helen Sari & 60 & 80 & Tuntas \\
18 & Zandi Akbar & 60 & 40 & Tidak Tuntas \\
& Nilai Tertinggi & & 80,00 & \\
& Nilai Terendah & & 30,00 & \\
& Nilai Rata-Rata & & 56,11 & \\
\hline
\end{tabular}


Keempat, refleksi. Refleksi dari hasil penelitian adalah sebagai berikut:

1. Model pembelajaran ini merupakan model pembelajaran yang baru bagi siswa. Hasil pengamatan menunjukkan bahwa beberapa siswa tidak mengetahui tentang konsep dari model pembelajaran kooperatif tipe group investigation yang diterapkan. Akibatnya, siswa bingung, kurang antusias, tidak aktif dalam kerja kelompok, serta cenderung diam saatt diskusi. Dengan demikian, guru perlu menjelaskan hal-hal yang perlu dilakukan siswa selama kegiatan pembelajaran terutama pada siswa yang belum mengerti.

2. Aktivitas dan hasil belajar siswa sudah mengalami peningkatan. Dengan demikian, guru perlu melanjutkan penggunaan model pembelajaran kooperatif tipe group investigation pad siklus II.

3. Beberapa siswa masih belum berani untuk menyampaikan hasil diskusi kelompoknya di depan kelas da nada juga siswa yang kurang berani dalam menanggapi hasil presentasi kelompok lain. Dengan demikian, guru perlu memberikan motivasi pada siswa untuk meningkatkan kepercayaan dirinya.

\section{Siklus II}

Kegiatan penelitian pada siklus II dilaksanakan pada hari Kamis, 8 September 2016 (Pertemuan ke-1 Siklus II), hari Selasa, 13 September 2016 (Pertemuan ke-2 Siklus II), dan hari Kamis, 15 September 2016 (Evaluasi Hasil Belajar Siklus II). Kegiatan penelitian pada siklus II terdiri atas perencanaan, pelaksanaan, pengamatan, dan refleksi.

Pertama, perencanaan. Kegiatan perencanaan terdiri atas: menganalisis standar kompetensi dan kompetensi dasar, menyusun rencana pelaksanaan pembelajaran (RPP), menetapkan materi bahan ajar, menyiapkan media pembelajaran, dan menyusun alat evaluasi pembelajaran

Kedua, pelaknaan. Kegiatan pelaksanaan terdiri atas tiga kegiaatn, yaitu kegiatan awal, kegiatan inti, dan kegiatan penutup. Kegiatan awal terdiri atas guru masuk kelas dan memberikan salam, siswa berdoa dipimpin oleh ketua kelas, guru mengondisikan kelas dan memeriksa kehadiran siswa, guru memberikan nomor pengamatan kepada siswa, guru menyampaikan apersepsi sebelum pembelajaran dimulai, dan guru menyampaikan tujuan pembelajaran yang akan dipelajari. Kegiatan inti dilakukan dengan eksplorasi, elaborasi, dan konfirmasi. Eksplorasi dilakukan dengan cara: guru menjelaskan kepada siswa tentang pembelajaran yang akan dilakukan yaitu dengan model cooperative learning tipe groupinvestigation, guru menyajikan subtopik permasalahan yang akan diinvestigasi dan melibatkan siswa dalam mengidentifikasi topik tersebut, guru meminta beberapa siswa menjawab pertanyaan untuk menggali pengetahuan awal siswa tentang materi yang akan diajarkan, guru membagi siswa menjadi beberapa kelompok. satu kelompok terdiri atas 5-6 orang orang siswa yang dibentuk secara heterogen, dan kelompok siswa merencanakan topik permasalahan yang akan dipelajari. Elaborasi dilakukan dengan cara siswa melakukan investigasi sesuai topik pada masing-masing kelompok dan setiap kelompok menyiapkan laporan akhir yaitu berupa rencana kegiatan presentasi yang akan disajikan di depan kelas.

Selanjutnya, konfirmasi dilakukan dengan cara masing-masing perwakilan kelompok mempresentasikan hasil diskusinya, guru bersama siswa mengevaluasi hasil presentasi yang telah disajikan oleh masing-masing kelompok, dan siswa dan guru melakukan refleksi terhadap kegiatan pembelajaran yang telah dilaksanakan. Kegiatan penutup terdiri 
atas: guru bersama siswa membuat kesimpulan. Guru memberikan tes akhir, guru memberikan tindak lanjut terhadap proses pembelajaran, dan guru menutup pembelajaran dengan salam dan ber doa.

Ketiga, pengamatan. Hasil belajar dalam penelitian ini dinilai berdasarkan tes dan didukung oleh evaluasi non-tes berupa pengamatan mengenai aktivitas siswa dalam kegiatan pembelajaran. Secara ringkas, hasil observasi disajikan pada Tabel 4. Aktivitas belajar siswa pada siklus II mengalami peningkatan dibandingkan dengan aktivitas belajar siswa pada siklus I. Hasil pengamatan yang disajikan pada Tabel 5 menunjukkan bahwa seluruh siswa mengikuti pembelajaran dengan antusias, mengikuti semua tahapan pembelajaran sesuai dengan aturan, dan dapat bekerja sama dalam kelompok. Sebagian besar siswa juga telah mampu menyampaikan hasil kerja kelompok di depan kelas dan juga telah berani menyampaikan tanggapan mengenai presentasi hasil diskusi kelompok lain.

Tabel 4 Hasil pengamatan aktivitas siswa pada akhir Siklus II

\begin{tabular}{clcr}
\hline No & \multicolumn{1}{c}{ Indikator } & Jumlah & Persen \\
\hline 1 & Siswa mengikuti pembelajaran dengan antusias & 18 & 100,00 \\
2 & Siswa mengikuti semua tahapan pembelajaran sesuai dengan & 18 & 100,00 \\
& aturan & 18 & 100,00 \\
3 & Siswa dapat bekerja sama dalam kelompok & 16 & 88,89 \\
4 & Siswa mampu menyampaikan hasil kerja kelompok di depan & & \\
& kelas & 15 & 83,33 \\
5 & $\begin{array}{l}\text { Siswa berani menyampaikan tanggapan mengenai presentasi } \\
\text { hasil diskusi kelompok lain }\end{array}$ & & \\
\hline
\end{tabular}

Selain evaluasi proses pembelajaran, penelitian pada siklus II juga melakukan evaluasi hasil belajar melalui tes. Hasil penelitian menunjukkan bahwa siswa memperoleh nilai terendah sebesar 40,0 dan nilai tertinggi sebesar 90,0 dengan nilai rata-rata sebesar 71,67. Apabila dibandingkan dengan KKM kompetensi dasar, $83,33 \%$ siswa memperoleh nilai yang lebih besar dibandingkan dengan KKM kompetensi dasar. Evaluasi hasil belajar siswa pada Siklus II disajikan pada Tabel 5.

Hasil penelitian yang disajikan pada Tabel 5 memperlihatkan bahwa nilai ratarata kelas yang diperoleh di akhir siklus II adalah 71,67. Nilai ini lebih besar dibandingkan dengan nilai rata-rata kelas pada akhir Siklus I yaitu 56,11. Peningkatan hasil juga terjadi pada presentase ketuntasan belajar siswa. Ketuntasan belajar siswa pada akhir siklus II adalah 83,33\%. Ketuntasan belajar siswa pada akhir siklus II juga meningkat dibandingkan dengan ketuntasan belajar siswa pada akhir siklus I sebesar $61,11 \%$. Hasil tersebut menunjukkan bahwa penggunaan model pembelajaran kooperatif tipe group investigation dalam pembelajaran dapat meningkatkan hasil belajar siswa pada mata pelajaran matematika.

Tabel 5 Hasil penelitian pada Siklus II

\begin{tabular}{clccl}
\hline No & \multicolumn{1}{c}{ Nama Siswa } & KKM & Nilai & \multicolumn{1}{c}{ Keterangan } \\
\hline 1 & Ainun Septia & 60 & 70 & Tuntas \\
2 & Aldo Noviardi & 60 & 50 & Tidak Tuntas \\
3 & Arif Manardi & 60 & 80 & Tuntas \\
4 & Aufa Alfia & 60 & 90 & Tuntas \\
5 & Defindra Pratama & 60 & 80 & Tuntas
\end{tabular}




\begin{tabular}{clccl}
6 & Delta Elfiani & 60 & 70 & Tuntas \\
7 & Deski Ahmad Farel & 60 & 60 & Tuntas \\
8 & Enjel Lika & 60 & 60 & Tuntas \\
9 & Hegil Alfaro & 60 & 90 & Tuntas \\
10 & Lendra Ahmad & 60 & 70 & Tuntas \\
11 & Marisa Dina & 60 & 60 & Tuntas \\
12 & Rizky Amanda & 60 & 90 & Tuntas \\
13 & Roni Irawan & 60 & 80 & Tuntas \\
14 & Susan Aulia & 60 & 50 & Tidak Tuntas \\
15 & Tesya Wulandari & 60 & 90 & Tuntas \\
16 & Vina Intan & 60 & 50 & Tidak Tuntas \\
17 & Trisia Helen Sari & 60 & 90 & Tuntas \\
18 & Zandi Akbar & 60 & 60 & Tuntas \\
& Nilai Tertinggi & & 90,00 & \\
& Nilai Terendah & & 40,00 & \\
& Nilai Rata-Rata & & 71,67 & \\
& Ketuntasan Belajar & & $83,33 \%$ & \\
\hline
\end{tabular}

Keempat, refleksi. Mengingat tindakan siklus II telah mengalami kemajuan yang cukup signifikan, baik berdasarkan aktivitas siswa maupun berdasarkan hasil belajar maka guru selaku peneliti memutuskan untuk menghentikan tindakan pada siklus II. Dengan demikian, penelitian tindakan kelas dianggap selesai. Meskipun demikian, guru dianjurkan untuk selalu memperbaiki kualitas pembelajaran.

\section{Analisis Hasil Belajar Siswa}

Hasil belajar siswa dilihat dari nilai rata-rata kelas dan ketuntasan belajar siswa. Hasil penelitian memperlihatkan bahwa nilai rata-rata kelas yang pada saat pratindakan hanya sebesar 37,78 meningkat menjadi 56,11 pada akhir siklus
I dan kembali meningkat menjadi 71,67 pada akhir siklus II. Apabila hasil pada akhir siklus II dibandingkan dengan hasil pada saat pratindakan maka diperoleh selisih sebesar 33,89 point. Selain peningkatan nilai rata-rata kelas, ketuntasan belajar siswa juga meningkat. Ketuntasan belajar siswa pada saat pratindakan hanya sebesar $44,44 \%$ meningkat menjadi $61,11 \%$ pada akhir siklus I dan kembali meningkat menjadi 83,33 pada akhir siklus II. Apabila hasil pada akhir siklus II dibandingkan dengan hasil pada saat pratindakan maka diperoleh selisih sebesar 38,89 point. Perbandingan hasil belajar yang diperoleh siswa pada saat pratindakan, siklus I, dan siklus II disajikan pada Gambar 1.

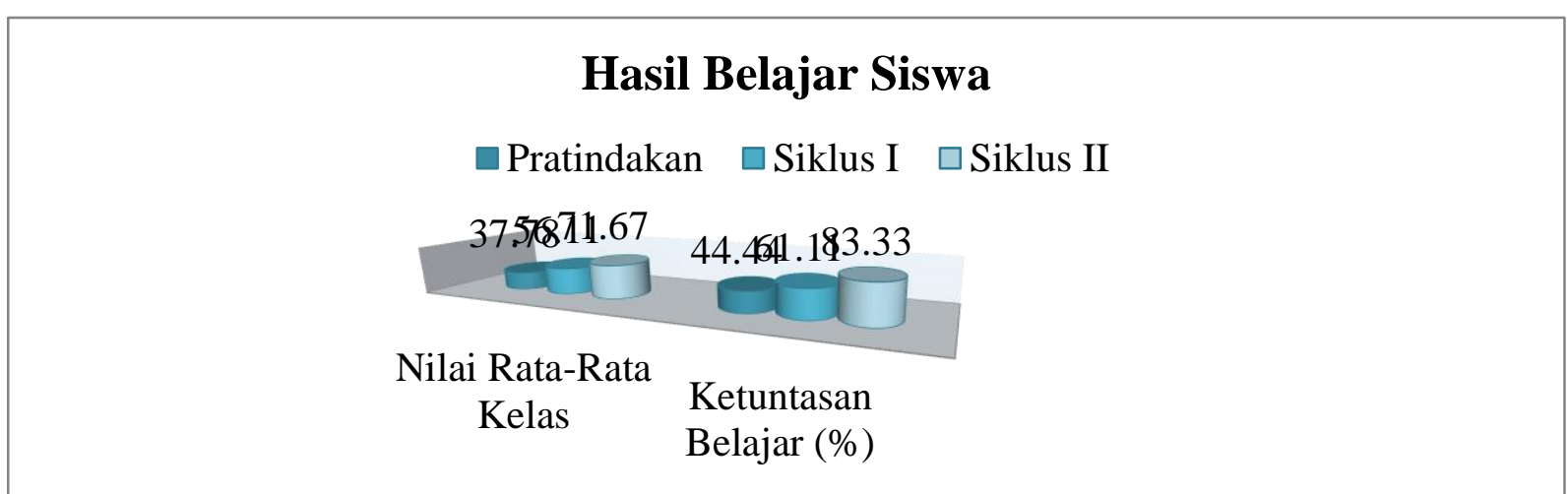

Gambar 3 Perbandingan hasil belajar yang diperoleh siswa pada saat pratindakan, siklus I, dan siklus II 
Berdasarkan hasil, penelitian ini menyimpulkan bahwa penerapan model pembelajaran kooperatif tipe group investigation juga meningkatkan hasil belajar siswa kelas VI di SDN. No. 028/XI Tanjung tahun 2016/2017. Hasil penelitian ini mendukung temuan Kustiyani (2013) bahwa penerapan model pembelajaran kooperatif tipe Group Investigation dapat meningkatkan aktivitas dan hasil belajar Matematika materi menjumlahkan dan mengurangkan berbagai bentuk pecahan siswa kelas V SD 1 Jurang Kabupaten Kudus tahun ajaran 2012/2013. Hasil penelitian ini juga mendukung temuan Hanisah, Saptuti, \& Budi (2014) bahwa penggunaan model pembelajaran kooperatif tipe group investigation dapat meningkatkan proses dan hasil belajar matematika tentang pecahan pada siswa kelas V SD yang ditunjukkan dengan meningkatnya nilai rata-rata kelas hasil belajar siswa tiap siklus. Hasil penelitian ini juga menguatkan hasil penelitian Setyadi, Suhartono, dan Warsiti (2015) bahwa penerapan model Group Investigation (GI) dapat meningkatkan hasil belajar Matematika siswa kelas V SD $\mathrm{N} 2$ Lamuk. Hasil penelitian ini juga mendukung hasil penelitian Pangestika, Budi, dan Joharman (2015) bahwa model kooperatif tipe GI dengan media model bangun ruang pada pembelajaran Matematika tentang bangun ruang telah dilaksanakan dengan langkah-langkah yang tepat sehingga mampu meningkatan proses dan hasil belajar siswa kelas V SDN 2 Panjer yang dibuktikan dengan persentase ketuntasan nilai proses dan hasil belajar. Selain itu, hasil penelitian ini juga semakin menguatkan hasil penelitian Safrida (2016) bahwa penerapan model pembelajaran kooperatif tipe Group Investigation dapat meningkatkan hasil belajar pada pembelajaran matematika di Kelas V MIN Rukoh Banda Aceh.

\section{SIMPULAN}

Penerapan model pembelajaran kooperatif tipe group investigation membawa perubahan pada aktivitas belajar siswa kelas VI di SDN. No. 028/XI Tanjung tahun 2016/2017. Seluruh siswa mengikuti pembelajaran dengan antusias, mengikuti semua tahapan pembelajaran sesuai dengan aturan, dan dapat bekerja sama dalam kelompok. Sebagian besar siswa juga telah mampu menyampaikan hasil kerja kelompok di depan kelas dan juga telah berani menyampaikan tanggapan mengenai presentasi hasil diskusi kelompok lain. Penerapan model pembelajaran kooperatif tipe group investigation juga meningkatkan hasil belajar siswa kelas VI di SDN. No. 028/XI Tanjung tahun 2016/2017. Hasil belajar siswa yang dilihat dari nilai rata-rata dan ketuntasan meningkat dibandingkan dengan hasil belajar pada saat pratindakan dan juga pada siklus I.

Berdasarkan temuan penelitian, pendidik diharapkan dapat menjadikan model pembelajaran kooperatif tipe group investigation sebagai alternatif yang dapat digunakan untuk meningkatkan hasil belajar siswa dalam mata pelajaran matematika; menjelaskan dengan detail mengenai kegiatan yang akan dilakukan selama kegiatan pembelajaran untuk meningkatkan partisipasi siswa; dan menggunakan model, pendekatan, strategi, metode, dan teknik pembelajaran yang variatif dan inovatif. Penelitian yang selanjutnya diharapkan juga dapat melakukan perbaikan agar diperoleh hasil yang lebih baik.

\section{DAFTAR PUSTAKA}

Aqib, Z., dkk. 2010. Penelitian Tindakan Kelas untuk Guru SD, SLB, dan TK. Bandung: Yrama Widya.

Arikunto, Suharsimi. 2013. Prosedur Penelitian Suatu Pendekatan Praktik. Jakarta: Rineka Cipta.

Hamalik, O. 2014. Kurikulum dan Pembelajaran. Jakarta: Bumi Aksara. 
Hanisah, S., Saptuti, T., \& Budi, H. S. 2014. Penggunaan Model Pembelajaran Kooperatif Tipe Group Investigation Dalam Peningkatan Pembelajaran Matematika Tentang Pecahan Pada Siswa Kelas V SD. Kalam Cendekia, Vol 2., No 1.

Irham, M., \& Wiyani, N. A. 2013. Psikologi Pendidikan: Teori dan Aplikasi dalam Proses Pembelajaran. Yogyakarta: Ar Ruzz Media.

Kunandar. 2013. Langkah Mudah Penelitian Tindakan Kelas Sebagai Pengembangan Profesi Guru. Jakarta: Rajawali Press.

Kustiyani. 2013. Implementasi Model Pembelajaran Kooperatif Tipe Group Investigation dalam Meningkatkan Hasil Belajar Matematika Siswa Kelas V SD 1 Jurang Kabupaten Kudus. Kudus: Pendidikan Guru Sekolah Dasar, Fakultas Keguruan dan Ilmu Pendidikan, Universitas Muria Kudus.

Pangestika, A., Budi, H. S., \& Joharman. 2015. Penerapan Model Kooperatif Tipe Group Investigation dengan Media Model Bangun Ruang dalam Peningkatan Pembelajaran Matematika pada Siswa Kelas V SDN 2 Panjer Tahun Ajaran 2014/2015. Kalam Cendekia, Vol 3, No 5.1 .

Rusman. 2011. Model- Model Pembelajaran. Jakarta:PT Raja Grafindo Persada.

Safrida. 2016. Penerapan Model Pembelajaran Kooperatif Tipe GI (Group Investigation) untuk Meningkatkan Hasil Belajar pada Pembelajaran Matematika di Kelas V MIN Rukoh Banda Aceh. Banda Aceh: Fakultas Tarbiyah dan Keguruan, Universitas Islam Negeri Ar-Raniry Darussalam.

Setiawan. 2006. Model Pembelajaran Matematika dengan Pendekatan
Investigasi. Yogyakarta: Depdinas PPPG Matematika.

Setyadi, E., Suhartono, \& Warsiti. 2015. Penerapan Model Kooperatif Tipe Group Investigation (GI) Untuk Meningkatkan Hasil Belajar Matematika Pada Siswa Kelas V SD. Kalam Cendekia, Vol 3, No 2.1.

Solihatin, E., \& Raharjo. 2007. Cooperative learning. Jakarta: Bumi Aksara.

Suprijono, A. 2012. Cooperative Learning Teori dan Aplikasi PAKEM. Yogyakarta: Pustaka Pelajar.

Susanto, A. 2013. Teori Belajar dan Pembelajaran di Sekolah Dasar. Jakarta: Kencana Prenada Media Group.

Suwangsih, E., \& Tiurlina. 2006. Model Pembelajaran Matematika. Bandung: UPI Press.

Trianto. 2007. Model-model Pembelajaran Inovatif Berorientasi Kontruktivistik. Jakarta: Prestasi Pustaka.

Trianto. 2009. Mendesain Model Pembelajaran Inovatif-Progresif. Jakarta: KENCANA Prenada Media Group.

Widiantara, K., Sedanayasa, G., \& Dibia, I. K. 2014. Pengaruh Model Pembelajaran Kooperatif Tipe Group Investigation (GI) Berbantuan Media Realita terhadap Hasil Belajar Matematika. e-Journal Mimbar $P G S D$ Universitas Pendidikan Ganesha Jurusan PGSD, Vol 2, No 1.

Winkel, W. S. 2009. Psikologi pengajaran. Yogyakarta: Media abadi. 